\title{
Bonellia albiflora: A Mayan Medicinal Plant That Induces Apoptosis in Cancer Cells
}

\author{
Rosa Moo-Puc, Juan Chale-Dzul, and Edgar Caamal-Fuentes \\ Unidad de Investigación Médica Yucatán, Unidad Médica de Alta Especialidad, Centro Médico Ignacio García Téllez, \\ Instituto Mexicano del Seguro Social, 41 No. $439 x 32$ y 34, Colonia Industrial CP, 97150 Mérida, YUC, Mexico
}

Correspondence should be addressed to Rosa Moo-Puc; moopuc@gmail.com

Received 3 April 2013; Revised 31 May 2013; Accepted 1 June 2013

Academic Editor: Ulysses Paulino de Albuquerque

Copyright (C) 2013 Rosa Moo-Puc et al. This is an open access article distributed under the Creative Commons Attribution License, which permits unrestricted use, distribution, and reproduction in any medium, provided the original work is properly cited.

Few studies have been carried out on the medical flora of Mexico's Yucatan Peninsula in search for new therapeutic agents, in particular against cancer. In this paper, we evaluated the cytotoxic potential of the extract of Bonellia albiflora, a plant utilized in the traditional Mayan medicine for treatment of chronic injuries of the mouth. We carried out the methanolic extracts of different parts of the plant by means of extraction with the Soxhlet equipment. We conducted liquid-liquid fractions on each extract with solvents of increasing polarity. All extracts and fractions were evaluated for cytotoxic activity versus four human cancer cell lines and one normal cell line through a tetrazolium dye reduction (MTT) assay in 96-well cell culture plates. The methanolic root-bark extract possessed much greater cytotoxic activity in the human oropharyngeal cancer cell line (KB); its hexanic fraction concentrated the active metabolites and induced apoptosis with the activation of caspases 3 and 8 . The results demonstrate the cytotoxic potential of the $B$. albiflora hexanic fraction and substantiate the importance of the study of the traditional Mayan medicinal plants.

\section{Introduction}

Traditional medicine is a practice that has been carried out from antiquity to our present time by inhabitants of the indigenous pueblos of Mexico, among which the Mayan population of the Yucatan Peninsula in Mexico is included. In the traditional Mayan medicine, plants are of great importance, which can be considered as evidence of their effectiveness for the control of many types of diseases. Likewise, they comprise one of the most important alternatives for health care, above all, in communities where primary health services are not accessible. In addition, they can be taken advantage of widely as a natural renewable resource. Together with what was previously described, the traditional medicine of the indigenous pueblos was recognized by the World Health Organization (WHO), which caused a powerful drive toward the research of medicinal plants [1].

The Mayan ethnobotanical literature in its majority is composed of historic or descriptive studies, in whose contents there predominates a compendium of diseases and treatments known to Mayan healers of distinct eras $[2,3]$. The
Mayan people knew of and treated distinct diseases, including those of infectious origin (intestinal infections, infectious dermatitis, and respiratory infections), chronic diseases (asthma, fatigue, nephritis, and hypertension), and psychological-type diseases (insomnia, nervousness, and hysteria). In addition, they cured other illnesses such as the following: abscesses; calluses; corns, hard protuberances; polyps; tumors; and warts or sores, generally tangible or visible on the skin $[1,4]$.

In the traditional Mayan medicine of the Yucatan Peninsula, "cancer" is known as an illness or a set of illnesses that can manifest themselves as an affectation of the skin or subadjacent muscle mass, or an affectation in the form of pain in some internal organ. The term alludes to a difficult-to-cure illness or a one with a disagreeable aspect (when it affects the skin); if it is an internal cancer, the patient's semblance reveals the disease. The old inhabitants assigned names in the Mayan language to this set of symptoms; in the Mayan tongue, "cancer" is known as "tsunuz" or "tsunuztacan", and hard protuberances or tumors are known as "chu'uchum" $[3,5]$. 
Prior studies have demonstrated that the extracts of plants utilized in the traditional Mayan medicine for the treatment of the signs and symptoms suggestive of cancer possess cytotoxic activity [6]. Similarly, two studies conducted on two species of the genus Bonellia (Bonellia macrocarpa and Bonellia flammea) from the Yucatan Peninsula reveal the presence of novel compounds, such as active agents with anticarcinogenic activity $[7,8]$. Within this context, the Yucatan Peninsula has five species of the genus Bonellia, among which the species B. macrocarpa, B. flammea, and B. albiflora are employed in the traditional Mayan medicine for the treatment of the dermatological-type afflictions $[5,9,10]$. Of these three species, only B. albiflora has not been the object of any phytochemical or biological activity study. B. albiflora is denominated "Si'ik" in the traditional Mayan medicine and is used as an antitussive for the treatment of skin and mouth wounds and to relieve toothache pain [10]. In this work, we proposed an evaluation of the cytotoxic potential of the organic extracts of B. albiflora.

\section{Materials and Methods}

2.1. Plant Material. Bonellia albiflora (Lundell) B. Ståhl and Källersjö was collected from different Localities of the State of Yucatan, Mexico, during the summer of 2010. Plant material was identified and authenticated by taxonomists from the Department of Natural Resources of the Scientific Research Center of Yucatan (CICY).

2.2. Chemicals. Dulbecco's modified Eagle's medium (DMEM), heat-inactivated fetal bovine serum (FBS), and penicillin and streptomycin (PS) were purchased from Gibco, Carlsbad, CA, USA. The 3-(4-5-dimethylthiazol2-yl)-2,5-diphenyl tetrazolium bromide (MTT), dimethyl sulfoxide (DMSO), and etoposide were purchased from Sigma, St. Louis, MO, USA. Caspase assay kits and apoptotic DNA laddering kit were purchased from BioVision Research Products, Palo Alto, CA, USA.

2.3. Extraction and Fractionation. Each vegetal part was separated, dried, and pulverized. Dried powder of the separated plant material $(100 \mathrm{~g})$ was exhaustively extracted using a Soxhlet apparatus at $60^{\circ} \mathrm{C}$ of temperature with methanol $(500 \mathrm{~mL})$. The supernatants were filtered and evaporated under vacuum by means of a rotaevaporator to obtain a dried extract. The methanol extract of each vegetal material (10 mg) was suspended in $20 \mathrm{~mL}$ methanol : water $(1: 3)$ and extracted successively using $50 \mathrm{~mL}$ of solvents of increasing polarity: hexane, dichloromethane, and ethyl acetate, such that the final residue extract was an aqueous fraction. The fingerprint of active hexane extract $(5 \mathrm{mg}$ ) was obtained for gas chromatography-mass spectrometry (GC-MS).

2.4. Cell Lines and Culture. Cell lines of the oropharyngeal carcinoma (KB ATCC-CCL-17), laryngeal carcinoma (Hep2), cervix adenocarcinoma (HeLa ATCC-CCL-2), and cervix squamous carcinoma (SiHa ATCC-CCL-35) as well as one normal cell line, canine cell kidney (MDCK ATCC-CCL34), from the American Type Culture Collection (ATCC) were kindly provided by Veronica Vallejo-Ruíz from the East Biomedical Research Center-IMSS. The cells were cultured in DMEM medium, containing 10\% SFB supplemented with 100 units/mL penicillin $\mathrm{G}$ and $100 \mu \mathrm{g} / \mathrm{mL}$ streptomycin in $5 \%$ $\mathrm{CO}_{2}-95 \%$ humidified air at $37^{\circ} \mathrm{C}$.

2.5. Cytotoxicity Assay. The cytotoxicity was determined by the MTT assay according to the method described by Denizot and Lang [11] with some modifications. Briefly, $5 \times 10^{3}$ viable cells from each cell line were seeded in a 96-well plate and incubated for $24-48 \mathrm{~h}$. When cells reached $>70 \%$ confluence, the medium was replaced and the cells were treated with the extract dissolved in DMSO (maximum concentration of $0.05 \%$ ) at 2.34 to $300 \mathrm{~g} / \mathrm{mL}$. After $48 \mathrm{~h}$ of incubation, $10 \mu \mathrm{L}$ MTT $(5 \mathrm{mg} / \mathrm{mL})$ was added to each well and incubated at $37^{\circ} \mathrm{C}$ for $4 \mathrm{~h}$. The medium was removed, and the formazan precipitate was dissolved in $100 \mu \mathrm{L}$ of acidified isopropanol $(0.4 \mathrm{~N} \mathrm{HCl})$. The optical density was determined with a spectrophotometer at $540 \mathrm{~nm}$. Cells treated with $0.05 \%$ DMSO and docetaxel were used as negative and positive controls, respectively. The concentration of the extract that killed 50\% of the cells $\left(\mathrm{CC}_{50}\right)$ was calculated by GraphPad Prism 4.00 software. All determinations were performed in triplicate. MDCK cell line was used to evaluate the selective index (SI) of extracts. SI is defined as the ratio of cytotoxic activity from normal cell and cancer cell lines.

2.6. GC-MS Analysis. The chromatographic separation was carried out by GC-MS analysis on an Agilent gas chromatograph, model $6890 \mathrm{~N}$, coupled to a mass selective detector, model 5975B. Compounds were separated on a DB-5 ms capillary column $(30 \mathrm{~m} \times 0.32 \mathrm{~mm}$ i.d., $0.25 \mu \mathrm{m}$ film thickness $)$ (J\&W Scientific, Folsom, CA, USA). One microliter of the sample was injected into GC-MS using split mode $(50: 1)$. The injector temperature was $250^{\circ} \mathrm{C}$. The column temperature was programmed as follows: initial temperature at $160^{\circ} \mathrm{C}$ for $3 \mathrm{~min}, 10^{\circ} \mathrm{C} / \mathrm{min}$ to $240^{\circ} \mathrm{C}, 240^{\circ} \mathrm{C}$ for $2 \mathrm{~min}, 5^{\circ} \mathrm{C} / \mathrm{min}$ to $250^{\circ} \mathrm{C}$, $250^{\circ} \mathrm{C}$ for $10 \mathrm{~min}, 5^{\circ} \mathrm{C} / \mathrm{min}$ to $300^{\circ} \mathrm{C}$, and $300^{\circ} \mathrm{C}$ for $10 \mathrm{~min}$. Mass detector conditions were the following: electronic impact (EI) mode at $70 \mathrm{eV}$; source temperature: $230^{\circ} \mathrm{C}$; scanning rate: $1 \mathrm{scan} / \mathrm{s}$; mass acquisition range: $20-600 \mathrm{amu}$; solvent delay, $4 \mathrm{~min}$. Carrier gas was helium at $1 \mathrm{~mL} / \mathrm{min}$. Volatile components were tentatively identified by comparing their mass spectra using NIST Standard Reference Database Version NIST 05 for Windows. An authentic standard of bonediol compound was kindly provided by Dr. PerazaSánchez from CICY.

2.7. Analysis of DNA Fragmentation. DNA fragmentation was determined according to the method described by Tong et al. [12]. Briefly, the cells were treated with the extract at 10 and $50 \mu \mathrm{g} / \mathrm{mL}$ and incubated for 6,12 , and $24 \mathrm{~h}$. After incubation, the cells were harvested by centrifugation and washed twice in ice-cold PBS. An apoptotic DNA laddering kit (BioVision apoptotic DNA ladder extraction kit) was used to isolate DNA according to the manufacturer's protocol; the DNA in the samples was separated on $1.5 \%$ agarose gel containing $1 \mu \mathrm{g} / \mathrm{mL}$ of ethidium bromide. DNA bands were visualized under ultraviolet illumination and were photographed. 
TABLE 1: Cytotoxicity $\left(\mathrm{CC}_{50}\right)$ of methanolic extracts from B. albiflora.

\begin{tabular}{|c|c|c|c|c|c|}
\hline \multirow{2}{*}{ Extract } & \multicolumn{5}{|c|}{ Cell lines $\mathrm{CC}_{50} \mu \mathrm{g} / \mathrm{mL}$ (selective index) } \\
\hline & MDCK & $\mathrm{KB}$ & $\mathrm{HeLa}$ & Hep-2 & $\mathrm{SiHa}$ \\
\hline Leaves & 91.39 & $23.85(3.83)$ & $47.05(1.94)$ & $35.20(2.59)$ & $47.45(1.92)$ \\
\hline Stem bark & 249.40 & $62.30(4.00)$ & NA & $72.30(3.45)$ & NA \\
\hline Root bark & 173.52 & $12.64(13.72)$ & $31.85(5.44)$ & $35.34(4.91)$ & $31.50(5.50)$ \\
\hline Docetaxel & 1.10 & $0.23(4.78)$ & $0.20(5.50)$ & $0.08(13.75)$ & $0.32(3.43)$ \\
\hline
\end{tabular}

NA: no activity $>200 \mu \mathrm{g} / \mathrm{mL}$.

2.8. Assays of Caspases Activities. Caspases 3, 8, and 9 activities were performed using FLICE/Caspase Colorimetric assay kit, following the manufacturer's protocols. Briefly, $5 \times$ $10^{6}$ cells treated with 10 or $50 \mu \mathrm{g} / \mathrm{mL}$ extract for 6,12 , or $24 \mathrm{~h}$ were harvested, washed with PBS, and centrifuged at $800 \times \mathrm{g}$ for $10 \mathrm{~min}$ at $4^{\circ} \mathrm{C}$. The cell pellets were resuspended in $50 \mu \mathrm{L}$ lysis buffer and incubated on ice for $10 \mathrm{~min}$ before being centrifuged at $10,000 \times \mathrm{g}$ for $1 \mathrm{~min}$. The supernatant was collected in a $1.5 \mathrm{~mL}$ tube and kept on ice. After measuring protein concentration, $200 \mu \mathrm{g}$ of protein was dissolved in $50 \mu \mathrm{L}$ cell lysis buffer. The reaction buffer with $10 \mathrm{mM}$ DDT was added to each sample. Finally, a specific substrate for each caspase (DEVD- $\rho$ NA, IETD- $\rho$ NA, and LEHD- $\rho$ NA) was added to the samples, incubated at $37^{\circ} \mathrm{C}$ for $1 \mathrm{~h}$, and read at $405 \mathrm{~nm}$. The enzyme activity was expressed as fold over control sample.

\section{Results and Discussion}

3.1. Cytotoxic Activity of Methanolic Extracts. The cytotoxicity results of the methanolic extracts from different parts of $B$. albiflora are summarized in Table 1 . The root bark's methanolic extract exhibited the most interesting cytotoxic activity compared to extracts of $B$. albiflora leaves and stem bark, with a $\mathrm{CC}_{50}$ of $12-31 \mu \mathrm{g} / \mathrm{mL}$ on the four human cancer cell lines. $\mathrm{KB}$ cell line showed a greater sensitivity to the extract with a $\mathrm{CC}_{50}$ of $12.64 \mu \mathrm{g} / \mathrm{mL}$. The nontumor canine kidney cell line MDCK was less sensitive to the effects of the extract with an SI of $>5$ in the cell lines evaluated (Table 1). The US National Cancer Institute (NCI) has proposed that crude extracts with potential cytotoxic activity are those presenting a $\mathrm{CC}_{50}$ of $\leq 30 \mu \mathrm{g} / \mathrm{mL}$; thus, this extract was identified as important for future studies [13]. These data are similar to those obtained in active B. macrocarpa-root methanolic extracts on human cell lines: $\mathrm{KB}$, prostate adenocarcinoma (PC3), cervix squamous carcinoma (SiHa), breast adenocarcinoma (MCF-7), cervix adenocarcinoma (HeLa), and laryngeal carcinoma (Hep-2) [6].

The extract of leaves was the second in greatest activity, only on $\mathrm{KB}$ cell line with a $\mathrm{CC}_{50}$ of $23.85 \mu \mathrm{g} / \mathrm{mL}$ according to NCI criteria, followed by that of the stem bark's extract, which was less cytotoxic to KB and Hep-2 cell lines.

3.2. Cytotoxic Activity of Fractions. The methanolic extracts of different parts of the plant were fractionated with solvents of increasing polarity for later cytotoxicity studies in the cell lines. The hexanic fraction obtained from the liquid-liquid partitioning of the methanolic extract of root bark (HFBa) presented superior cytotoxic effects compared to the original extract, with a $\mathrm{CC}_{50}$ between 2 and $27 \mu \mathrm{g} / \mathrm{mL}$ in the distinct cell lines (Table 2). The hexanic fraction's SI also improved compared to the original extract in the cell lines evaluated $(\mathrm{SI}=5-54)$. The methanolic fractions of the bark and leaves extracts were not active at concentrations of $>200 \mu \mathrm{g} / \mathrm{mL}$ (data not shown).

Previously, we conducted a bioguided study to evaluate the antiproliferative activity of $B$. macrocarpa, yielding the isolation of the compound bonediol, which showed moderate activity in cancer cell lines [8]. However, the present study did not show cytotoxic effects with HFBa comparable to the original methanolic extract in the cell lines evaluated (Table 2). An explanation to these results may be that bonediol inhibits some point of cellular proliferation (cycle cell or replication of DNA), while the effects that are observed in the cytotoxic assay are damage or general toxicity (apoptosis or necrosis) [14].

HFBa presented better cytotoxic effects compared to bonediol and was more selective toward the tumor than toward normal cells; SI is considered an indicator of biological activity and is not related to cytotoxicity if the SI is $>10$ [15]. In this regard, only $\mathrm{HFBa}$ satisfied these criteria and was more potent in the $\mathrm{KB}$ cell line with a $\mathrm{CC}_{50}$ of $2.73 \mu \mathrm{g} / \mathrm{mL}$; this cell line is related to oral cancer and is in agreement with the plant's use in the traditional Mayan medicine for chronic oral lesions [10], a term that could be related with cancer.

3.3. GC-MS Analysis. Identification and chemical analysis of bioactive hexane fraction by GC-MS is displayed in Table 3 . The chromatogram revealed a total of eight peaks, six of which were identified by the database: dodecanoic acid; tridecanoic acid; 2-nonyl-malonic acid, dimethyl ester; stigmasta-7,16-dien-3-ol; 9,19-Cyclo-lanost-24-en-3-ol; and bonediol. This last one was identified by retention time and comparison of the mass spectrum of an authentic standard previously isolated from B. macrocarpa [8]. The major components found were the following: 2-nonyl-malonic acid, dimethyl ester (37.39\%), followed by stigmasta-7,16-dien-3-ol (13.63\%), dodecanoic acid (13.22\%), 9,19-Cyclo-lanost-24en-3-ol (9.90\%), and bonediol (8.98\%). Unidentified components with retention times of $8.092(6.22 \%)$ and 14.207 $(5.38 \%)$, as well as $\mathrm{n}$-tridecanoic acid (5.25\%), were minor compounds in the HFBa (Figure 1).

Bonediol was isolated from the methanolic extract of B. macrocarpa roots as a bioactive component. In this work, we detected the presence of this compound at a low concentration; thus, it could be referred to as a possible 
TABLE 2: Cytotoxicity of organic fractions from methanolic extract of B. albiflora root bark and bonediol.

\begin{tabular}{|c|c|c|c|c|c|}
\hline \multirow{2}{*}{ Extract } & \multicolumn{5}{|c|}{ Cell lines $\mathrm{CC}_{50} \mu \mathrm{g} / \mathrm{mL}$ (selective index) } \\
\hline & MDCK & $\mathrm{KB}$ & $\mathrm{HeLa}$ & Hep-2 & $\mathrm{SiHa}$ \\
\hline Hexane & 148.48 & $2.73(54.38)$ & $14.29(10.39)$ & $15.48(9.59)$ & $27.02(5.49)$ \\
\hline Dichloromethane & NA & NA & NA & NA & NA \\
\hline Ethyl acetate & NA & NA & NA & NA & NA \\
\hline Aqueous & NA & NA & NA & NA & NA \\
\hline Bonediol & 139.71 & $80.60(1.73)$ & $115.45(1.21)$ & $92.50(1.51)$ & $54.40(2.56)$ \\
\hline Docetaxel & 1.10 & $0.23(4.78)$ & $0.20(5.50)$ & $0.08(13.75)$ & $0.32(3.43)$ \\
\hline
\end{tabular}

NA: no activity $>200 \mu \mathrm{g} / \mathrm{mL}$.

TABLE 3: Chemical composition of hexane fraction of B. albiflora.

\begin{tabular}{|c|c|c|c|c|}
\hline $\begin{array}{l}\text { Peak } \\
\text { no. }\end{array}$ & $\begin{array}{l}\text { Retention } \\
\text { time (min) }\end{array}$ & $\begin{array}{l}\text { Peak relative } \\
(\%)\end{array}$ & $m / z$ (relative abundance $\%)$ & Component \\
\hline 1 & 5.802 & 13.221 & $\begin{array}{l}200(10), 171(10), 157(30), 143(10), 129(40), 115(20), 101(15), 85(30) \\
73(100), 60(85), 43(70), 29(40) .\end{array}$ & Dodecanoic acid \\
\hline 2 & 7.012 & 5.256 & $\begin{array}{l}214(10), 185(10), 171(35), 157(5), 143(5), 129(40), 115 \text { (25), } 97 \text { (15), } \\
85(20), 73(95), 60(85), 43(70), 29(35) .\end{array}$ & Tridecanoic acid \\
\hline 3 & 8.091 & 6.222 & $\begin{array}{l}208 \text { (19), } 166(13), 152(100), 137 \text { (18), } 121(6), 107 \text { (5), } 91 \text { (13), } 77 \text { (13), } \\
55(5), 41(13), 28(19) .\end{array}$ & Unidentified \\
\hline 4 & 9.826 & 37.396 & $\begin{array}{l}259(5), 156(7), 145(70), 132(100), 113(13), 100(20), 87(18), 69 \text { (16), } \\
55(33), 41(31), 29(13) .\end{array}$ & $\begin{array}{l}\text { 2-Nonyl-malonic acid, dimethyl } \\
\text { ester }\end{array}$ \\
\hline 5 & 14.1927 & 5.381 & $\begin{array}{l}350(100), 209(80), 195(24), 179(48), 164(12), 151(16), 136(2) \\
75(8), 57(8), 43(20), 28(26)\end{array}$ & Unidentified \\
\hline 6 & 16.389 & 8.983 & 294 (70), 209 (13), 179 (10), 153 (100), 139 (5), 123 (20), 77 (9), 41 (20). & Bonediol \\
\hline 7 & 37.548 & 13.634 & $\begin{array}{l}412(22), 369(10), 341(10), 300(15), 271(80), 246(20), 207(90) \\
173(10), 147(40), 107(43), 81(75), 55(80), 43(100), 28(40)\end{array}$ & Stigmasta-7,16-dien-3-ol \\
\hline 8 & 39.632 & 9.907 & $\begin{array}{l}426(25), 411(100), 393(45), 259(10), 215(10), 187(15), 173(15) \\
161(15), 135(25), 109(40), 69(90), 55(40), 41(45) .\end{array}$ & 9,19-Cyclo-lanost-24-en-3-ol \\
\hline
\end{tabular}

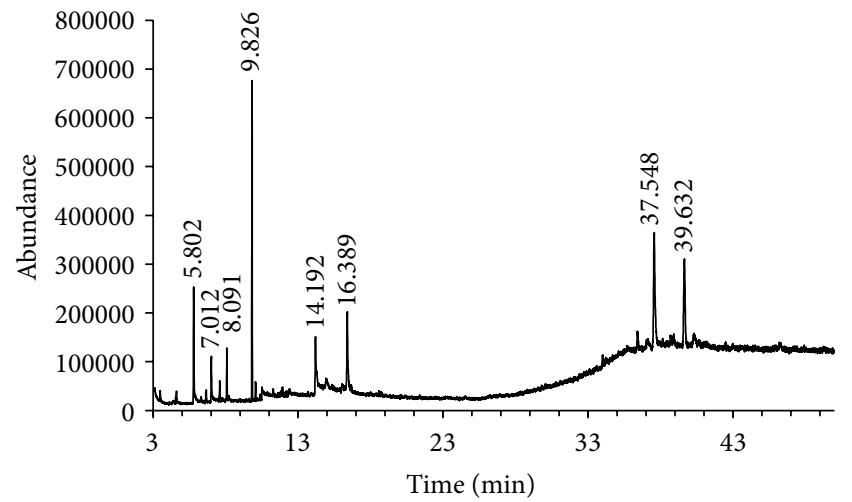

Figure 1: Gas chromatography of HFBa.

chemotaxonomic marker. Additionally, in other species such as $B$. pungens, a triterpene has been isolated [16], and from $B$. ruscifolia, two triterpenes have been isolated, without reports of biological activity $[17,18]$. In this work, we have only found evidence of the presence of a lanosterol-derived triterpene in the active hexanic fraction. In addition, we detected a ubiquitinated sterol, a derivative of stigmasterol. To our knowledge, this is the first time that both compounds have been reported in this genus.
In recent years, not only has the study of medically bioactive compounds from plants become more frequent, but also that of the plant extracts themselves or the mixture of compounds that together could yield better biological activity than that exhibited by a single compound has, moreover, become frequent [19]. In this work, the components are described as the fingerprinting of HFBa performed by GCMS for future standardizations.

3.4. DNA Fragmentation. We observed that the methanol extract of the roots of $B$. albiflora showed typical morphology of apoptosis (data not shown) on KB cell lines. Similarly, $\mathrm{HFBa}$ was shown to induce apoptotic morphology on $\mathrm{KB}$ cell lines. These results led us to evaluate whether the hexanic fraction that demonstrated the greatest cytotoxicity and apoptosis morphological characteristics in the $\mathrm{KB}$ cell line could induce this process; thus, we evaluated the fragmentation of DNA, typical of the process of apoptosis. DNA fragmentation was registered from lesser to greater magnitude within a treatment concentration range of 10 or $50 \mu \mathrm{g} / \mathrm{mL}$ and an incubation-time range of 6-24 h. Figure 2 shows typical DNA fragmentation in KB cells after treatment with $50 \mu \mathrm{g} / \mathrm{mL}$ HFBa and an $18 \mathrm{~h}$ incubation period. Several studies have shown the apoptotic effect of certain plant methanolic extracts [20-24]. However, few studies have 


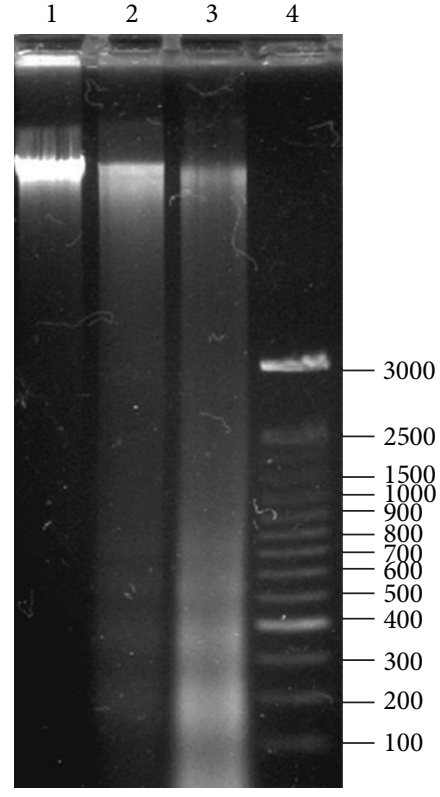

FIGURE 2: Effect of hexane root extract Bonellia macrocarpa on DNA fragmentation in $\mathrm{KB}$ cells. After the treatment of the cells with a concentration of $50 \mu \mathrm{g} / \mathrm{mL}$ of B. macrocarpa for $12 \mathrm{~h}$, DNA was isolated and separated on 1.5\% agarose gel. DNA was stained with ethidium bromide and visualized under UV light. Lanes 1 to 4 : lane 1 (negative control): DNA collected from untreated $\mathrm{KB}$ cells after $18 \mathrm{~h}$; lane 2 (positive control): DNA collected from KB cells treated with $50 \mu \mathrm{g} / \mathrm{mL}$ of etoposide after $18 \mathrm{~h}$; lane 3: DNA collected from $\mathrm{KB}$ cells treated with $50 \mu \mathrm{g} / \mathrm{mL}$ of extract after $18 \mathrm{~h}$; lane 4 : DNA molecular weight marker.

investigated the chemical characteristics of the compounds that may possess this activity. In those few studies, it was generally found that the low-polarity organic fractions are responsible for the apoptotic effect on the cell lines, coinciding with the results obtained in this study $[25,26]$.

It is unknown whether the compounds in HFBa are responsible for apoptosis induction, but it cannot be attributed to a single compound such as bonediol that, although present in the extract, requires high concentrations to induce apoptosis (data not shown), unlike HFBa, which induces DNA fragmentation at $10 \mu \mathrm{g} / \mathrm{mL}$. With regard to the above, in addition to bonediol, we report the presence of dodecanoic acid and a derivative of stigmasterol as components of HFBa. These compounds have been associated with cytotoxic activity observed for the hexane fraction of Crocus sativus [27]. Furthermore, some authors have demonstrated that derivatives of stigmasterol showed significant cytotoxic activity in cancer cell lines that depended on apoptosis [2831]. In particular, spinasterol (stigmasta-7, 22-dien-3beta-ol) has demonstrated decreased incidence of skin tumors in vivo [32]. In fact, spinasterol and the derivative reported in this study differ in double enlace at position 22 in spinasterol and position 16 for the stigmasterol derivative. Perhaps, stigmasta-7, 22-dien-3beta-ol could contribute to cytotoxic activity observed in this study. In addition, it is known that lanostanes are a group of tetracyclic triterpenoids derived

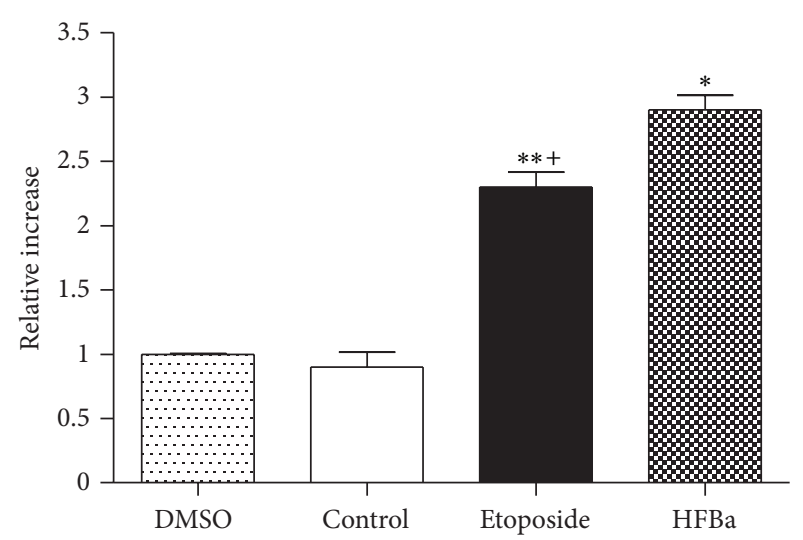

FIgure 3: Treatment during six hours with Bonellia macrocarpa hexane fraction induced caspase 8 activation. Treatments were the following: DMSO (0.05\%), control (no treatment), etoposide $(50 \mu \mathrm{g} / \mathrm{mL})$, and HFBa $(50 \mu \mathrm{g} / \mathrm{mL})$. Each symbol is the mean \pm SD relative caspase activation from three assays, normalized with the control group. One-way ANOVA: $F(3,11)=96.84, P<0.0001$; Tukey's post-hoc test: ${ }^{*} P<0.001$ versus DMSO and control group; ${ }^{* *} P<0.001$ versus DMSO and control group; ${ }^{+} P<0.05$ versus HFBa.

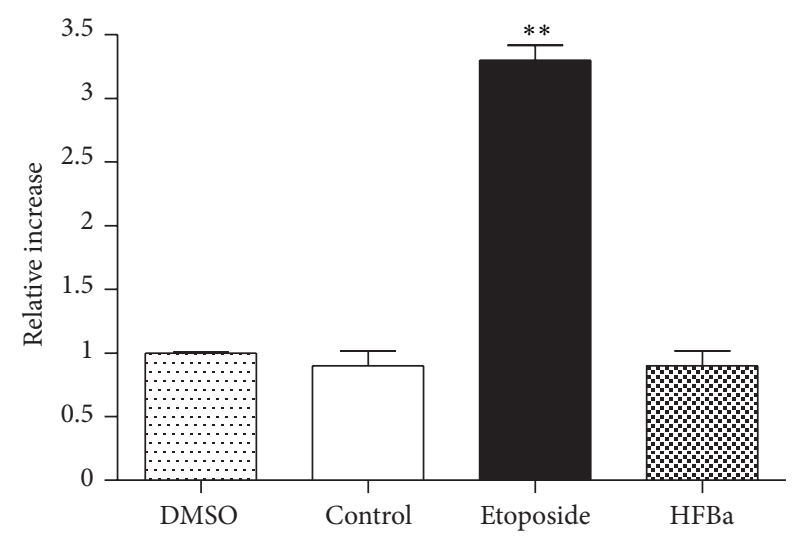

FIgURE 4: Treatment during 12 hours with Bonellia macrocarpa hexane fraction did not induce caspase 9 activation. Treatments were the following: DMSO (0.05\%), control (no treatment), etoposide $(50 \mu \mathrm{g} / \mathrm{mL})$, and HFBa $(50 \mu \mathrm{g} / \mathrm{mL})$. Each symbol is the mean \pm SD relative caspase activation from three assays, normalized with the control group. One-way ANOVA: $F(3,11)=140.11, P<0.0001$; Tukey's post-hoc test: ${ }^{* *} P<0.001$ versus all groups.

from lanosterol, which have multiple activities against cancer cells including the induction of apoptosis [33, 34]. Possibly, the lanostane- and stigmasterol-type compounds reported in the active hexane fraction have a degree of cytotoxic activity and an effect of inducing apoptosis. It is likely that several compounds present in the hexane fraction act synergistically to induce cytotoxicity and apoptosis.

3.5. Analysis of the Activity of Caspases. To know whether the mechanism of activation of DNA fragmentation was induced by activation of apoptosis via the intrinsic or extrinsic pathway, we evaluated the activity of caspases that is characteristic 


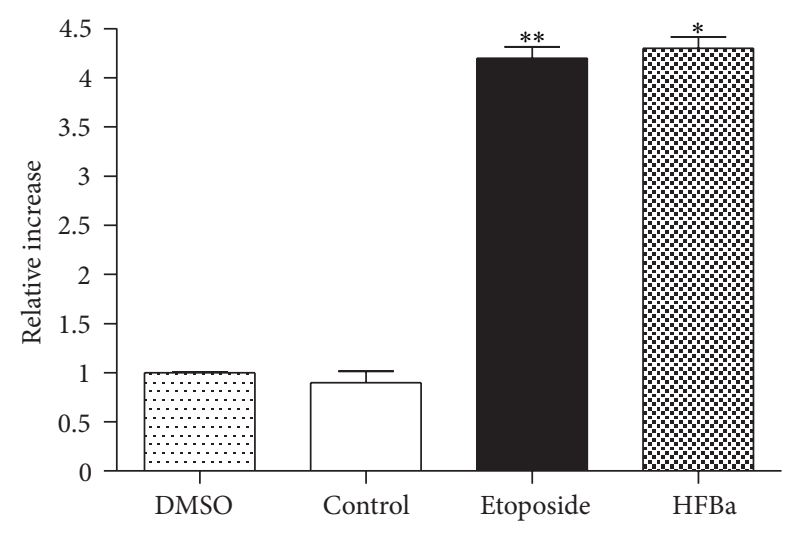

FIgURE 5: Treatment during 12 hours with Bonellia macrocarpa hexane fraction induced caspase 3 activation. Treatments were the following: DMSO (0.05\%), control (no treatment), etoposide $(50 \mu \mathrm{g} / \mathrm{mL})$, and HFBa $(50 \mu \mathrm{g} / \mathrm{mL})$. Each symbol is the mean \pm SD relative caspase activation from three assays, normalized with the control group. One-way ANOVA: $F(3,11)=363.2, P<0.0001$; Tukey's post-hoc test: ${ }^{* *} P<0.001$ versus DMSO and control group; ${ }^{*} P<0.001$ versus DMSO and control group.

of each. The incubation periods were of $2,4,6$, and $12 \mathrm{~h}$ to obtain an activation profile. Caspase 8 was activated after $6 \mathrm{~h}$ of treatment with $50 \mu \mathrm{g} / \mathrm{mL}$ of $\mathrm{HFBa}$; the increase was three times greater compared to control cells without treatment (negative control) (Figure 3). No increase was observed in the activation of caspase 8 in the 2,4 , and $12 \mathrm{~h}$ incubation periods. Caspase 9 was not activated in KB cells after treatment with $50 \mu \mathrm{g} / \mathrm{mL}$ of $\mathrm{HFBa}$ during $2-12 \mathrm{~h}$, which suggests a lack of apoptosis activation by the intrinsic pathway (Figure 4). Caspase 3 activity increased four folds compared to that of the control in HFBa-treated cells, which is in agreement with caspase 8 activation (Figure 5). The increase of caspase 8 activity is typical of extrinsic-pathway activation of apoptosis, which in turn activates other procaspases, among these is caspase 3, which in turn leads to the degradation of nuclear proteins such as laminin A, fodrin, actin, and gelsolin. It also leads to the release of the caspase-activated DNase protein inhibitor (ICAD), converting it into the caspase-activated DNase (CAD) enzyme, whose objective is DNA degradation [35], as depicted in Figure 2. Given that caspase 9 was not activated, we conclude that $B$. albiflora induces apoptosis by the extrinsic pathway. This evidences the great potential that this fraction possesses as an alternative or adjunct therapy in the treatment of cancer. In the literature are several studies of extracts from plants and their effects on the induction of the intrinsic apoptosis pathway [36-42]. However, few studies have shown the activation of the extrinsic apoptosis pathway by plant extracts; for example, the methanolic extract of Paeonia suffruticosa induces apoptosis in the human stomach cancer cell line (AG3) [43], and dandelion root extract has the capacity to induce apoptosis in the chronic myelomonocytic leukemia cell line (CMML) and in drug-resistant melanoma cells $[44,45]$. It is not known which of the compounds present in the active fraction of $B$. albiflora may cause activation of the extrinsic pathway of apoptosis. Regardlessly, there are reports of the induction of apoptosis by activation of extrinsic signaling mediated by natural and synthetic triterpenoids [46-48]. Additionally, the lanostane-type triterpenoid, polyporenic acid C isolated from Poriacocos, induces caspase-8-mediated apoptosis in human lung cancer [49]. Notably, $\beta$-sitosterol (structural isomer of stigmasterol) has been shown to induce apoptosis by activation of the extrinsic pathway, activating Fas signaling in human breast cancer cells [50]. This might suggest that both the triterpene and sterol components of the extract used in this study would have a major role in the induction of apoptosis mediated by the activation of the extrinsic pathway.

To our knowledge, this is the first time it has been demonstrated that the extract of a plant employed in the traditional Mayan medicine possesses an effect on apoptosis. Future studies will be directed toward standardizing the extract and evaluating the latter with in vivo models. Additional studies are necessary for elucidating the compounds responsible for the observed cytotoxic activity and their exact mechanism of apoptosis.

\section{Conclusions}

The hexanic fraction of $B$. albiflora roots exerts cytotoxic effects and induces apoptosis via the extrinsic pathway, which suggests its potential for the treatment of cancer. We suggest the complete isolation of the components present in the hexane fraction of $B$. albiflora for evaluation in the cytotoxic assay and induction of apoptosis, to elucidate which are the active compounds as well as to understand the mechanism of action.

\section{Conflict of Interests}

The authors declare that they have no conflict of interests and no financial connection to any commercial entity mentioned in the paper.

\section{Acknowledgments}

This paper was supported by SEP-CONACYTCB-2010156755. The authors would like to thank L. Torres-Tapia from the Biotechnology Department of the Scientific Research Center of Yucatan (CICY) for the technical assistance during the GC-MS analysis. The authors are, moreover, grateful to Dr. Glenn Jackson for the English language review of the paper.

\section{References}

[1] J. M. Spieler, "World Health Organization, the special programme of research, development and research training in human reproduction task force on indigenous plants for fertility regulation," Korean Journal of Pharmacognosy, vol. 12, pp. 9497, 1981.

[2] R. M. Mendieta, Plantas Medicinales Del Estado De Yucatán, CECSA, Yucatán, México, 1st edition, 1981.

[3] G. Balam, Cosmogonia Y Uso Actual De Las Plantas Medicinales De Yucatán, Universidad Autónoma de Yucatán, Yucatán, México, 1992. 
[4] G. M. Cragg and D. J. Newman, "Plants as a source of anticancer agents," Journal of Ethnopharmacology, vol. 100, no. 1-2, pp. 72-79, 2005.

[5] R. Osadao, El Libro del Judío o Medicina Doméstica, Descripción de las Virtudes de las Yerbas Medicinales de Yucatán, Mérida, Yucatan Mexico, 1834.

[6] E. Caamal-Fuentes, L. W. Torres-Tapia, P. Simá-Polanco, S. R. Peraza-Sánchez, and R. Moo-Puc, "Screening of plants used in Mayan traditional medicine to treat cancer-like symptoms," Journal of Ethnopharmacology, vol. 135, no. 3, pp. 719-724, 2011.

[7] A. Sánchez-Medina, L. M. Peña-Rodríguez, F. May-Pat et al., "Identification of sakurasosaponin as a cytotoxic principle from Jacquinia flammea," Natural Product Communications, vol. 5, no. 3, pp. 365-368, 2010.

[8] E. Caamal-Fuentes, L. W. Torres-Tapia, R. Cedillo-Rivera, R. Moo-Puc, and S. R. Peraza-Sánchez, "Bonediol, a new alkyl catechol from Bonellia macrocarpa," Phytochemistry Letters, vol. 4, no. 3, pp. 345-347, 2011.

[9] B. Ståhl and M. Källersjö, "Reinstatement of Bonellia (Theophrastaceae)," Novon, vol. 14, no. 1, pp. 115-118, 2004.

[10] R. Arellano, G. Flores, and G. Tun, "Leguminosae," in Nomenclatura, Forma de Vida, Uso, Manejo y Distribución de las Especies Vegetales de la Península de Yucatán, pp. 312-380, Universidad Autónoma de Yucatán, Yucatán, México, 2003.

[11] F. Denizot and R. Lang, "Rapid colorimetric assay for cell growth and survival - Modifications to the tetrazolium dye procedure giving improved sensitivity and reliability," Journal of Immunological Methods, vol. 89, no. 2, pp. 271-277, 1986.

[12] X. Tong, S. Lin, M. Fujii, and D.-X. Hou, "Echinocystic acid induces apoptosis in HL-60 cells through mitochondriamediated death pathway," Cancer Letters, vol. 212, no. 1, pp. 2132, 2004.

[13] R. I. Geran, N. H. Greenberg, M. M. Macdonald, A. M. Schumacher, and B. J. Abbott, "Protocols for screening chemical agents and natural products against animal tumors and other biological systems," Cancer Chemotherapy Reports, vol. 3, pp. 59-61, 1972.

[14] R. Moo-Puc, D. Robledo, and Y. Freile-Pelegrín, "In vitro cytotoxic and antiproliferative activities of marine macroalgae from Yucatán, Mexico," Ciencias Marinas, vol.35, no. 4, pp. 345358, 2009.

[15] C. Vonthron-Sénécheau, B. Weniger, M. Ouattara et al., "In vitro antiplasmodial activity and cytotoxicity of ethnobotanically selected Ivorian plants," Journal of Ethnopharmacology, vol. 87, no. 2-3, pp. 221-225, 2003.

[16] A. L. Okunade and D. F. Wiemer, "Jacquinonic acid, an antrepellent triterpenoid from Jacquinia pungens," Phytochemistry, vol. 24, no. 6, pp. 1203-1205, 1985.

[17] K. Bhattacharyya, T. Kar, P. K. Dutta, G. Bocelli, and L. Righi, "Dimethyl oleana-13(18),15(16)-diene-3 $\beta, 28$-diacetate," Acta Crystallographica Section C, vol. 55, no. 6, pp. 992-994, 1999.

[18] K. Bhattacharyya, T. Kar, P. Kumar, B. Achari, and G. Bocelli, "Oleana-12(13), 15(16)-diene-3 $\alpha, 28$ diyl diacetate," Acta Cristallographica, vol. 56, no. 2, pp. 60-61, 2000.

[19] H. J. Lee, H. Y. Kang, C. H. Kim et al., "Effect of new rotenoid glycoside from the fruits of Amorpha fruticosa LINNE on the growth of human immune cells," Cytotechnology, vol. 52, no. 3 , pp. 219-226, 2006.

[20] P. Bontempo, D. Rigano, A. Doto et al., "Genista sessilifolia DC extracts induce apoptosis across a range of cancer cell lines," Cell Proliferation, vol. 46, no. 2, pp. 183-192, 2013.
[21] J.-W. Chon, J.-H. Sung, E.-J. Hwang, and Y.-K. Park, "Chlorella methanol extract reduces lipid accumulation in and increases the number of apoptotic 3T3-L1 cells," Annals of the New York Academy of Sciences, vol. 1171, pp. 183-189, 2009.

[22] K.-J. Jo, M.-R. Cha, M.-R. Lee, M.-Y. Yoon, and H.-R. Park, "Methanolic extracts of Uncaria rhynchophylla induce cytotoxicity and apoptosis in HT-29 human colon carcinoma cells," Plant Foods for Human Nutrition, vol. 63, no. 2, pp. 77-82, 2008.

[23] S. Nadova, E. Miadokova, L. Alfoldiova et al., "Potential antioxidant activity, cytotoxic and apoptosis-inducing effects of Chelidonium majus L. extract on leukemia cells," Neuroendocrinology Letters, vol. 29, no. 5, pp. 649-652, 2008.

[24] T. N. Hasan, G. Shafi, N. A. Syed et al., "Methanolic extract of Nigella sativa seed inhibits $\mathrm{SiHa}$ human cervical cancer cell proliferation through apoptosis," Natural Product Communications, vol. 8, no. 2, pp. 213-216, 2013.

[25] C. P. Preethy, R. Padmapriya, V. S. Periasamy et al., "Antiproliferative property of $n$-hexane and chloroform extracts of Anisomelesmalabarica (L). R. Br. in HPV16-positive human cervical cancer cells," Journal of Pharmacology and Pharmacotherapeutics, vol. 3, no. 1, pp. 26-34, 2012.

[26] A. Chicca, B. Adinolfi, E. Martinotti et al., "Cytotoxic effects of Echinacea root hexanic extracts on human cancer cell lines," Journal of Ethnopharmacology, vol. 110, no. 1, pp. 148-153, 2007.

[27] C.-J. Zheng, L. Li, W.-H. Ma, T. Han, and L.-P. Qin, "Chemical constituents and bioactivities of the liposoluble fraction from different medicinal parts of Crocus sativus," Pharmaceutical Biology, vol. 49, no. 7, pp. 756-763, 2011.

[28] Y. Ahmed, M. H. Sohrab, S. M. Al-Reza, F. S. Tareq, C. M. Hasan, and M. A. Sattar, "Antimicrobial and cytotoxic constituents from leaves of Sapium baccatum," Food and Chemical Toxicology, vol. 48, no. 2, pp. 549-552, 2010.

[29] R. Chowdhury, R. B. Rashid, M. H. Sohrab, and C. M. Hasan, "12 $\alpha$-hydroxystigmast-4-en-3-one: a new bioactive steroid from Toona ciliata (Meliaceae)," Pharmazie, vol. 58, no. 4, pp. 272273, 2003.

[30] K. H. Kim, S. U. Choi, C. S. Kim, and K. R. Lee, "Cytotoxic steroids from the trunk of Berberis koreana," Bioscience, Biotechnology and Biochemistry, vol. 76, no. 4, pp. 825-827, 2012.

[31] A. B. Awad and C. S. Fink, "Phytosterols as anticancer dietary components: evidence and mechanism of action," Journal of Nutrition, vol. 130, no. 9, pp. 2127-2130, 2000.

[32] I. M. Villasenor and A. P. Domingo, "Anticarcinogenicity potential of spinasterol isolated from squash flowers," Teratogenesis, Carcinogenesis, and Mutagenesis, vol. 20, pp. 99-105, 2000.

[33] J. L. Ríos, I. Andújar, M. C. Recio, and R. M. Giner, "Lanostanoids from fungi: a group of potential anticancer compounds," Journal of Natural Products, vol. 75, no. 11, pp. 20162044, 2012.

[34] L. Zhou, Y. Zhang, L. A. Gapter, H. Ling, R. Agarwal, and K.Y. Ng, "Cytotoxic and anti-oxidant activities of lanostane-type triterpenes isolated from Poriacocos," Chemical and Pharmaceutical Bulletin, vol. 56, no. 10, pp. 1459-1462, 2008.

[35] J. F. R. Kerr, C. M. Winterford, and B. V. Harmon, "Apoptosis: its significance in cancer and cancer therapy," Cancer, vol. 73, no. 8, pp. 2013-2026, 1994.

[36] R. R. Somasagara, M. Hegde, K. K. Chiruvella, A. Musini, B. Choudhary, and S. C. Raghavan, "Extracts of strawberry fruits induce intrinsic pathway of apoptosis in breast cancer cells and inhibits tumor progression in mice," PLoS ONE, vol. 7, no. 10, Article ID e47021, 2012. 
[37] J.-Q. Yu, Y. Yin, J.-C. Lei et al., "Activation of apoptosis by ethyl acetate fraction of ethanol extract of Dianthus superbus in HepG2 cell line," Cancer Epidemiology, vol. 36, no. 1, pp. e40e45, 2012.

[38] A. C. Tan, I. Konczak, I. Ramzan, and D. M.-Y. Sze, "Native Australian fruit polyphenols inhibit cell viability and induce apoptosis in human cancer cell lines," Nutrition and Cancer, vol. 63, no. 3, pp. 444-455, 2011.

[39] H. C. Pal, I. Sehar, S. Bhushan, B. D. Gupta, and A. K. Saxena, "Activation of caspases and poly (ADP-ribose) polymerase cleavage to induce apoptosis in leukemia HL-60 cells by Inula racemosa," Toxicology in Vitro, vol. 24, no. 6, pp. 1599-1609, 2010.

[40] Y.-C. Tien, J.-Y. Lin, C.-H. Lai et al., "Carthamus tinctorius L. prevents LPS-induced TNF $\alpha$ signaling activation and cell apoptosis through JNK1/2-NF $\kappa$ B pathway inhibition in $\mathrm{H} 9 \mathrm{c} 2$ cardiomyoblast cells," Journal of Ethnopharmacology, vol. 130, no. 3, pp. 505-513, 2010.

[41] M. E. Juan, U. Wenzel, V. Ruiz-Gutierrez, H. Daniel, and J. M. Planas, "Olive fruit extracts inhibit proliferation and induce apoptosis in HT-29 human colon cancer cells," Journal of Nutrition, vol. 136, no. 10, pp. 2553-2557, 2006.

[42] M.-J. Liu, Z. Wang, H.-X. Li, R.-C. Wu, Y.-Z. Liu, and Q.-Y. Wu, "Mitochondrial dysfunction as an early event in the process of apoptosis induced by woodfordin I in human leukemia K562 cells," Toxicology and Applied Pharmacology, vol. 194, no. 2, pp. 141-155, 2004.

[43] H. S. Choi, H. S. Seo, J. H. Kim, J. Y. Um, Y. C. Shin, and S. G. Ko, "Ethanol extract of Paeonia suffruticosa Andrews (PSE) induced AGS human gastric cancer cell apoptosis via fasdependent apoptosis and MDM2-p53 pathways," Journal of Biomedical Science, vol. 19, article 82, 2012.

[44] S. Pandey, S. J. Chatterjee, P. Ovadje, M. Mousa, and C. Hamm, "The efficacy of dandelion root extract in inducing apoptosis in drug-resistant human melanoma cells," Evidence-Based Complementary and Alternative Medicine, vol. 2011, Article ID 129045, 11 pages, 2011.

[45] P. Ovadje, C. Hamm, and S. Pandey, "Efficient induction of extrinsic cell death by dandelion root extract in human chronic Myelomonocytic Leukemia (CMML) cells," PLoS ONE, vol. 7, no. 2, Article ID e30604, 2012.

[46] W.-S. Suh, Y. S. Kim, A. D. Schimmer et al., "Synthetic triterpenoids activate a pathway for apoptosis in AML cells involving downregulation of FLIP and sensitization to TRAIL," Leukemia, vol. 17, no. 11, pp. 2122-2129, 2003.

[47] K. H. Kim, H. S. Seo, H. S. Choi, I. H. Choi, Y. C. Shin, and S.-G. Ko, "Induction of apoptotic cell death by ursolic acid through mitochondrial death pathway and extrinsic death receptor pathway in MDA-MB-231 cells," Archives of Pharmacal Research, vol. 34, no. 8, pp. 1363-1372, 2011.

[48] Z. D. Nassar, A. F. A. Aisha, N. Idris et al., "Koetjapic acid, a natural triterpenoid, induces apoptosis in colon cancer cells," Oncology Reports, vol. 27, no. 3, pp. 727-733, 2012.

[49] H. Ling, L. Zhou, X. Jia, L. A. Gapter, R. Agarwal, and K.-Y. Ng, "Polyporenic acid C induces caspase-8-mediated apoptosis in human lung cancer A549 cells," Molecular Carcinogenesis, vol. 48, no. 6, pp. 498-507, 2009.

[50] A. B. Awad, M. Chinnam, C. S. Fink, and P. G. Bradford, “ $\beta$ Sitosterol activates Fas signaling in human breast cancer cells," Phytomedicine, vol. 14, no. 11, pp. 747-754, 2007. 


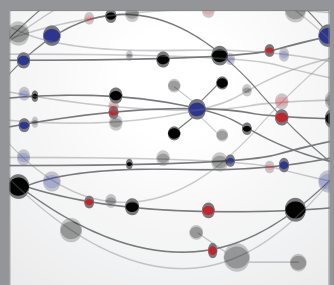

The Scientific World Journal
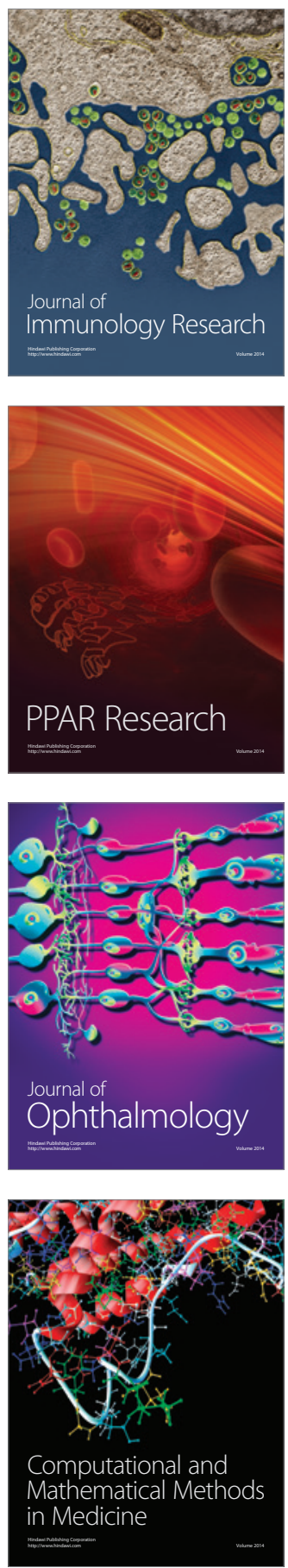

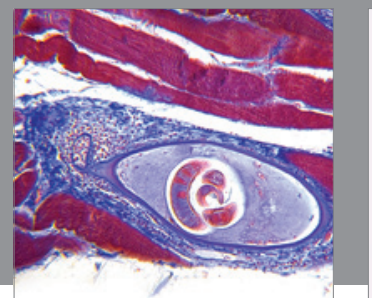

Gastroenterology

Research and Practice
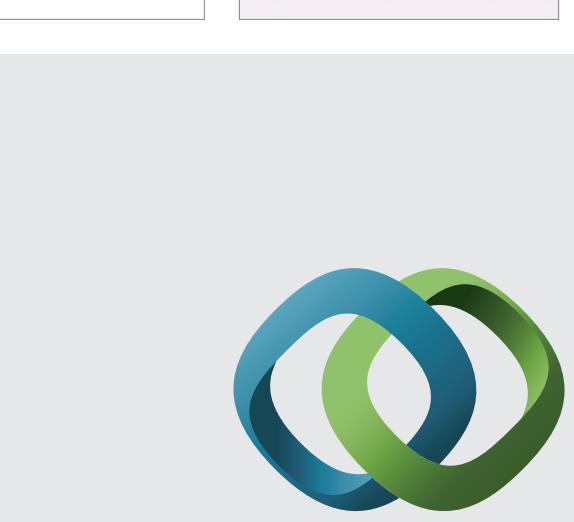

\section{Hindawi}

Submit your manuscripts at

http://www.hindawi.com
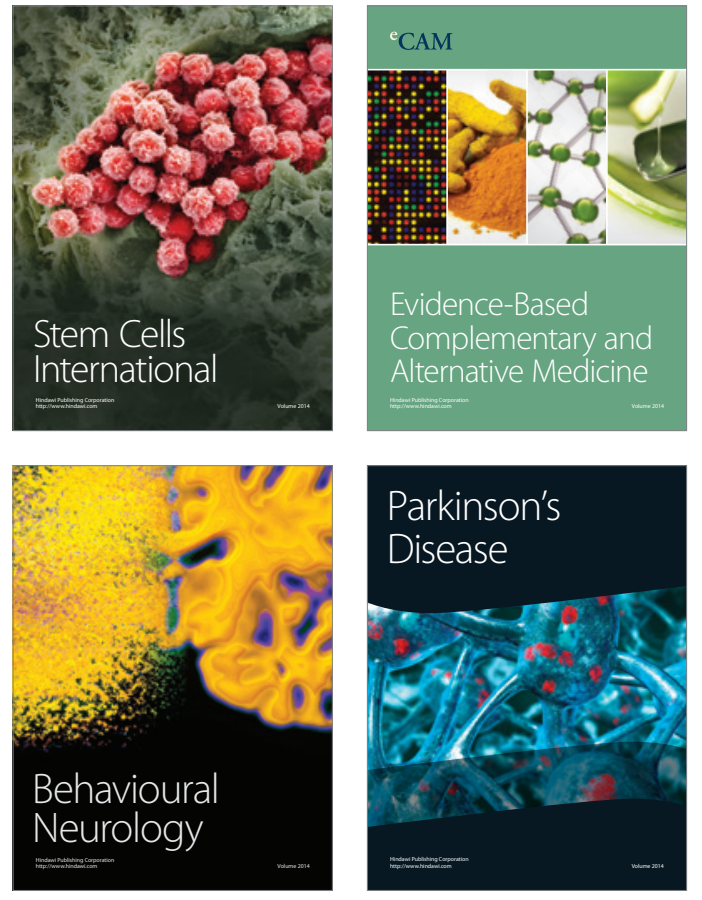
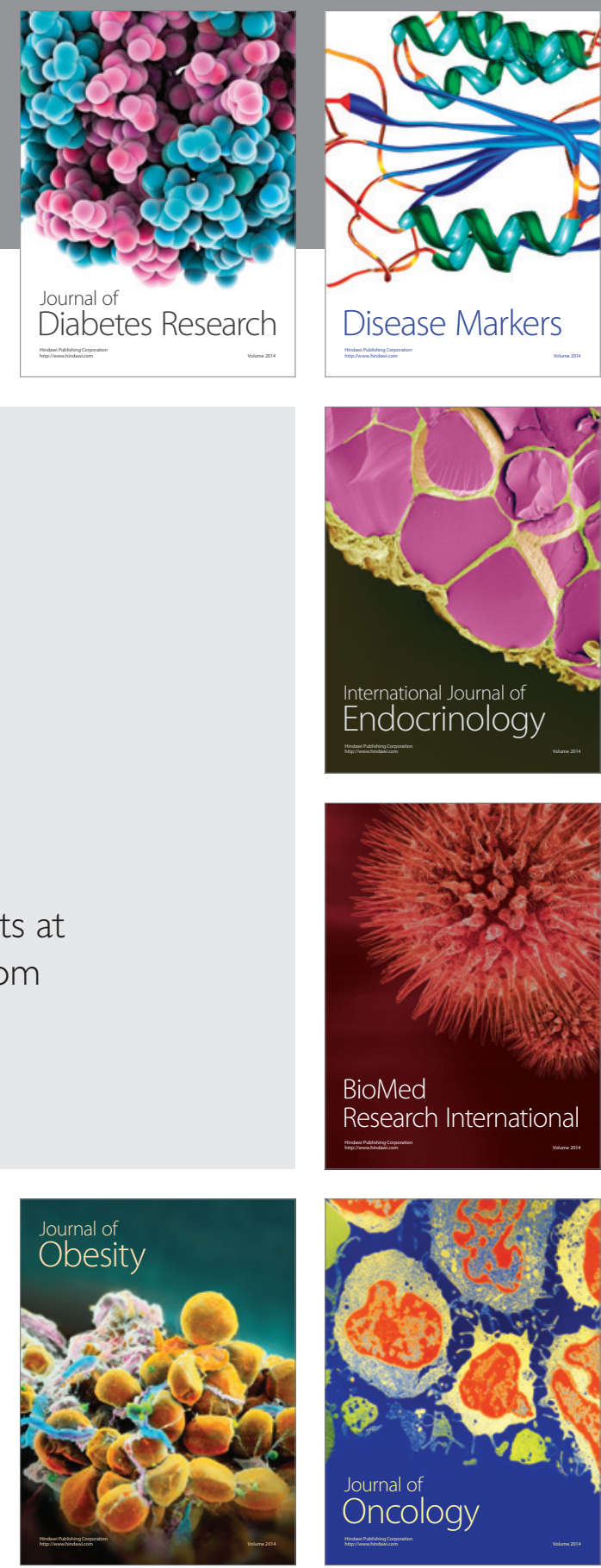

Disease Markers
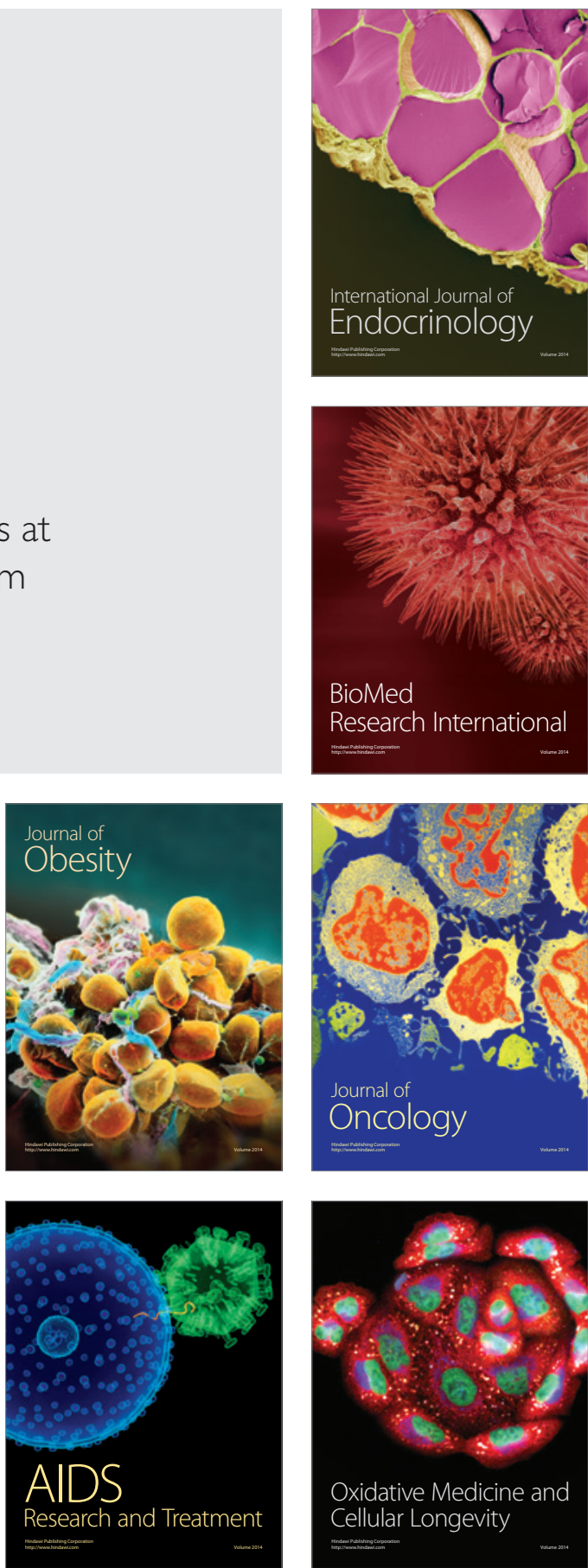